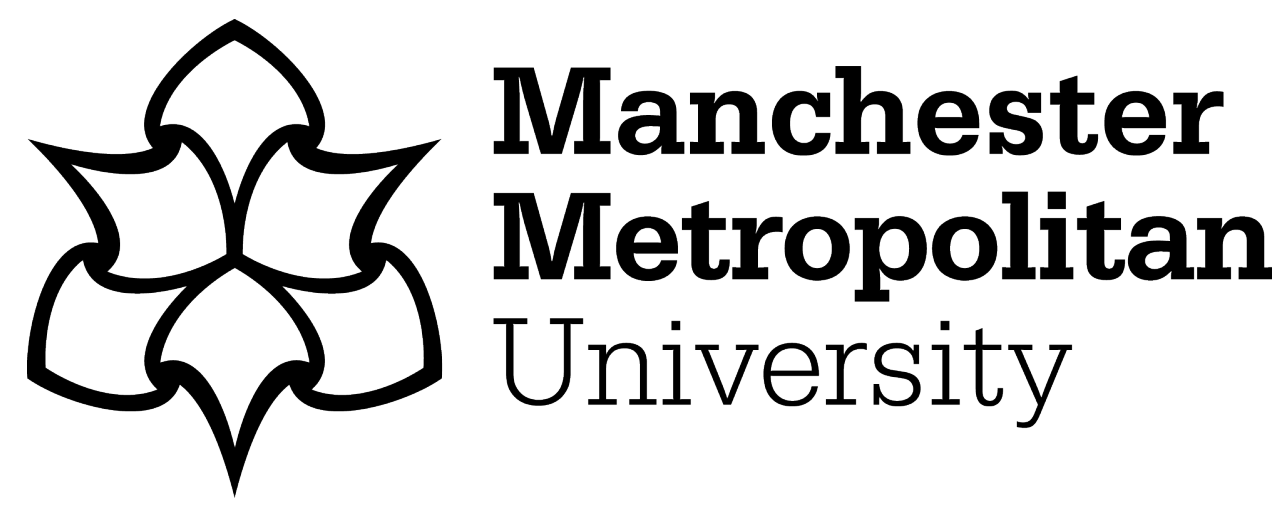

Pijetlovic, Katarina ORCID logoORCID: https://orcid.org/0000-0002-98014827 (2016) EU Competition Law and Organisational Rules. In: The Legacy of Bosman: Revisiting the Relationship Between EU Law and Sport. Springer, pp. 117-151. ISBN 9462651205

Downloaded from: https://e-space.mmu.ac.uk/624313/

Version: Accepted Version

Publisher: Springer

DOI: https://doi.org/10.1007/978-94-6265-120-3_6

Please cite the published version 


\title{
Chapter 7: EU Competition Law and Organisational Rules
}

\author{
Katarina Pijetlovic*
}

\section{Introduction}

The relationship between EU competition law and organisational (regulatory) rules in sport was originally formed in 1970s in the Walrave and Donà cases decided under free movement law. Therein, the Court of Justice of the European Union (CJEU) famously held that sport is subject to EU law 'only in so far as it constitutes economic activity [...]'. ${ }^{1}$ This has been reiterated by the Court on several occasions later on, most notably in Bosman, Deliège and Lehtonen. ${ }^{2}$ The required economic effect referred to in these cases presents a generally applicable jurisdictional threshold on the competences of EU institutions to act, as well as a constitutional limitation regarding the applicability of EU competition law. Apart from certain rules of the game (lex ludica $)^{3}$ and sport as a purely amateur pursuit, it is hard to imagine a rule passed by sport governing bodies that is completely devoid of economic effect in practice. All sporting rules and practices that $d o$ produce required economic effect may become subject to a compatibility analysis under the Treaty, including its competition articles.

Regardless of the constitutional competence to decide on the application of the competition articles to organisational rules in the sports sector, in Bosman and Deliège the Court avoided any discussion on the application of Articles 101 and 102 TFEU to sporting rules that produce economic effect. The two cases were decided exclusively under internal market provisions. Advocate Generals (AGs), however, did not leave us completely empty handed and both addressed this issue in their respective Opinions. Whereas AG Lenz in Bosman focused exclusively on weighing pro and anti-competitive features of the restrictive clauses and utilised an emerging commercial ancillarity as a method for a compatibility assessment, AG Cosmas in Deliège alluded to the possibility of using certain non-economic interests as a justification for the rules that restrict competition.

Three years after AG Cosmas' Opinion, the CJEU in Wouters ${ }^{4}$ accepted purely non-economic public interest justifications under Article 101(1) TFEU for agreements restrictive of the

\footnotetext{
* Katarina Pijetlovic, Senior Lecturer in EU Law at the Department of Law, Liverpool Hope University, e-mail: pijetlk@hope.ac.uk.

${ }^{1}$ Case 36/74 Walrave and Koch v. Union Cycliste Internationale and others [1974] ECR 1405 [hereinafter referred to as 'Walrave'], para 4; Case 13/76 Gaetano Donà v. Mario Mantero [1976] ECR 1333, para 12.

${ }^{2}$ Case C-415/93 Union Royale Belge Sociétés de Football Association and others v. Bosman and others [1995] ECR I-4921, para 73; Joined Cases C-51/96 and C-191/97 Christelle Deliège v. Ligue francophone de judo et disciplines associées ASBL [2000] ECR I-2549, para 41; Case C-176/96 Jyri Lehtonen and Castors Canada Dry Namur-Braine ASBL v. Fédération royale belge des sociétés de basket-ball ASBL (FRBSB) [2000] ECR I-2681, para 42.

${ }^{3}$ As defined by Foster 2006, $\mathrm{p} 421$. The rules of the game are, e.g. offside in football, the dimensions of a tennis court, and the number of fielded players.

${ }^{4}$ Case C-309/99 J.C.J Wouters, J.W. Savelbergh, Price Waterhouse Belastingadviseurs BV v. Algemene Raad van de Nederlandse Orde van Advocaten [2002] ECR I-1577.
} 
freedom of action. This case introduced the so-called regulatory ancillarity in the application of competition law and paved the way for the seminal judgement in Meca-Medina, ${ }^{5}$ which to date remains the only case on the organisational rules in sport decided by the Court under the EU antitrust provisions.

Prior to the passage of the Court's judgement in Meca-Medina a lot of uncertainty still surrounded the application of EU competition law to legal issues involving organisational rules of sport. Meca-Medina not only enhanced legal certainty, but also provided a modified analytical framework for such rules and practices by adopting the Wouters test in its entirety. It is therefore important to distinguish organisational rules from the rules intended to regulate revenue-producing activities of the sporting bodies. The former involves activities on the market in which clubs and federations exploit their performances and commercial rights through, for instance, the sale of tickets and media rights for sports events, merchandising, as well as via activities on the supply market for buying and selling of players. Examples of organisational rules, on the other hand, include rules of the game, rules concerning selection criteria for sports competitions, 'at home and away from home' rules, rules preventing multiple ownership in club competitions, rules concerning the composition of national teams, antidoping rules and rules concerning transfer windows.

In 2007 the EU Commission published the White Paper on Sport accompanied by a Commission Staff Working Document. ${ }^{6}$ It summarised the EU competition law approach to the sports sector and provided examples of organisational rules in sport that are likely to infringe, as well as organisational rules likely not to infringe the competition provisions.

However, as emphasised by both the Court in Meca-Medina and by the Commission in the White Paper on Sport, there can be no automatic exclusion of any organisational sporting rule that produces economic effect from the scope of the Treaty. Their compatibility with EU competition provisions can only be made on a case-by-case basis within the analytical framework provided by Annex I of the Commission Staff Working Document that, among others, includes the Meca-Medina test. This contextual approach to regulatory rules is further complemented by the notion of the specificity of sport, included in Article 165(1) TFEU by the Lisbon Treaty amendments that entered into force on 1 December 2009.

This article states that ' $[\mathrm{t}]$ he Union shall contribute to the promotion of European sporting issues, while taking account of the specific nature of sport, its structures based on voluntary activity and its social and educational function' [emphasis added]. Prior to the passage of the Lisbon Treaty amendments, the sport-related public interest based on the specificity of the industry and its social and educational function was already taken into consideration and accepted by both the Court and the Commission in many internal market cases. This is significant for competition law as well due to the high level of convergence with the free movement area $^{7}$ and virtually uniform compatibility tests for organisational rules in sport.

\footnotetext{
${ }^{5}$ Case C-519/04 David Meca-Medina and Igor Majcen v. Commission [2006] ECR I-6991.

${ }^{6}$ Commission of the European Communities, White Paper on Sport, COM (2007) 391 final; Commission of the European Communities, Commission Staff Working Document, The EU and Sport: Background and Context, Accompanying Document to the White Paper on Sport, COM (2007) 391 final [hereinafter referred as 'Commission Staff Working Document'].

${ }^{7}$ Baquero Cruz 2002; Mortelmans 2011.
} 
Against this general background, this chapter explains the evolution of the law and policy concerning the application of Articles 101 and 102 TFEU to organisational rules in the sport sector.

\section{Sporting rules in internal market jurisprudence}

\subsection{Purely sporting rules: Walrave [1974] and Donà [1976]}

Apart from sporting rules that do not constitute an economic activity and therefore do not fall within the scope of the Treaty according to paragraph 4 of Walrave, the CJEU set out the test for the so-called purely sporting rules. In paragraph 8 of Walrave it made an exception for a directly discriminatory sporting rule on selection of athletes for national representative teams. Specifically, with regard to discrimination based on nationality as prohibited under Articles 18, 45 and 56 TFEU, the Court stated that such prohibition 'does not affect the composition of sport teams, in particular national teams, the formation of which is a question of purely sporting interest and as such has nothing to do with economic activity. ${ }^{8}$ It further added in paragraph 9 that 'this restriction on the scope of the provisions in question must however remain limited to its proper objective.' Accordingly, the Treaty would not apply to economic sporting activities as long as the motive for the proportionate rules was non-economic, or in other words, 'purely sporting'.

Two years later in $\operatorname{Dona}^{9}$ a football agent challenged the strict nationality and residence preconditions for participation in all non-amateur matches imposed by the Italian Football Federation. The challenged rules limited the right to participate in matches (as professional or semi-professional players) almost exclusively to Italian nationals. In paragraph 14 of Donà, the Court modified and restricted the rule in paragraph 8 of Walrave. The exception to prohibition on direct discrimination for the composition of national teams was reformulated and substituted with the exclusion of foreign players 'from participation in certain matches for the reasons which are not of an economic nature, which relate to the particular nature and context of such matches and are thus of sporting interest only'. Matches between national teams were mentioned only as an example of the kind of exclusion of players that fall under this category of sporting exception.

As acknowledged by AG Lenz in Bosman, Donà represents a limitation on paragraph 8 in Walrave. The Court rightly did not make a reference to that paragraph because it was aware that the question of the composition of sport teams may well be dominated by non-sporting motives. AG Lenz concluded that neither the basis nor the extent of the 'exception' can be deduced with certainty from these two judgments. ${ }^{10}$

Purely sporting rules are therefore the rules that are exempted, since they: (1) produce the required economic effect, (2) are based on non-economic, purely sporting motives, (3) relate to the particular nature and context of certain matches, and (4) are proportionate. According to some authors, the 'purely sporting' rules exception 'does not apply to sports teams, or to general

\footnotetext{
${ }^{8}$ Walrave, para 8.

${ }^{9}$ Case 13/76 Donà v Mantero (1976) ECR 1333.

${ }^{10}$ AG Lenz Opinion in Bosman, delivered on 20 September 1995, paras 138-139.
} 
rules on team composition, but only to nationality rules in national team sports'. ${ }^{11}$ It is indeed difficult to think of any other rule that would in practice align with the strict demands of this exception. However, as a matter of legal and judicial construction, such possibility exists and the Court has been citing this exception in its other judgments outside the context of nationality discrimination. $^{12}$

\subsection{Objectively justified rules: Bosman [1995], Lehtonen [2000], and Bernard [2010]}

Unlike purely sporting and inherent rules (discussed below), objectively justified rules in sport constitute restrictions under internal market law. Such restrictions can, however, be justified under the generally applicable objective justification framework as set out in Kraus and Gebhard. ${ }^{13}$ Accordingly, those rules that (1) pursued a legitimate aim compatible with the Treaty and were justified by pressing reasons of public interest, and (2) are compatible with the principle of proportionality do not breach the provisions on free movement of persons. ${ }^{14}$ Importantly, the assessment of sporting rules under the Gebhard-style framework involves a sensitive application of EU law to sport, ${ }^{15}$ and the recognition of the specificity of the sports industry. Unlike in ordinary cases, in sport cases the Court uses an alteration of the test for both directly and indirectly discriminatory rules. ${ }^{16}$ The Court was asked to consider the legality of organisational rules in sports under Article 45 TFEU in Bosman, Lehtonen, and Bernard. ${ }^{17}$

The facts of the Bosman case are well-known; it involved a directly discriminatory ' $3+2$ ' rule passed by Union of European Football Associations (UEFA) that placed quota on clubs in fielding foreign players and non-discriminatory transfer fee rules which restricted the professional activities of football players. With regard to the latter, in view of the considerable social importance of football in the EU, the Court acknowledged encouraging the recruitment and training of young players and maintaining the competitive balance between clubs as legitimate objectives. ${ }^{18}$ Conversely, it brushed aside the attempts to justify quotas on the basis of their alleged necessity to maintain the traditional link between each club and their country, to create a sufficient pool of top national players to be fielded in national representative team, and to maintain competitive balance between clubs. The fact that the quota rule was drawn up in collaboration with the Commission did not shield it from judicial scrutiny or provide any guarantees as to its compatibility with the Treaty, as the Commission does not have the power to authorise rules and practices contrary to the Treaty. Quotas were abolished by the Court, whereas the transfer fees for the expired contracts were found unsuitable for the attainment of the said objectives and also failed the proportionality test.

\footnotetext{
${ }^{11}$ Parrish and Miettinen 2008, p 100.

${ }^{12}$ Meca-Medina, para 25; Bosman, para 76.

${ }^{13}$ Case C-55/94 Gebhard [1995] ECR I-4165; Case C-19/92 Kraus [1993] ECR I-1663.

14 Ibid., paras 37 and 32.

15 Parrish and Miettinen 2008, p 73.

${ }^{16}$ Discriminatory measures normally can only benefit from the exhaustive list of Treaty-based exceptions such as public policy, public health, and public security, but not from an open list of justifications available to nondiscriminatory measures. Sport is an exception to this rule.

${ }^{17}$ Case C-325/08 Olympique Lyonnais SASP v. Olivier Bernard and Newcastle United FC [2010] ECR I-2177.

${ }^{18}$ Bosman, para 106.
} 
The Court considered that in the light of its answers under Article 45 TFEU, it was unnecessary to address the questions on interpretation of Articles 101 and 102 TFEU that were also referred to it for a preliminary ruling. However, AG Lenz in Bosman, entertained the arguments of the respondent that referred to the 'rule of reason', a concept applied in the US under Article 1 of the Sherman Act. While he acknowledged that Europe does not have the 'rule of reason' doctrine and instead uses Article 101(3) TFEU as a platform for exemption analysis, he nevertheless found a functional equivalent that existed at the time in the form of the $D L G$ case ${ }^{19}$ on commercial ancillarity, a precursor to Wouters case that contained the same basic approach to assessment of legality of restrictions as the core competition test applied to sporting rules today. ${ }^{20}$

In Lehtonen, the transfer of a basketball player did not take place within the specified time period, i.e. within the so-called 'transfer window' passed by the International Basketball Federation. A player that was not employed within the specified period could not play for his team in competitions for that season. Citing Bosman, the Court reiterated in paragraph 50 of Lehtonen that being fielded is the 'essential purpose of a professional player's activity' and the rules prohibiting fielding restrict the chances of being employed. Because they affected labour market access as opposed to the exercise of economic activity, transfer windows were not inherent rules, but instead restrictions to free movement that fell to be examined under the objective justification framework. ${ }^{21}$ The Court found them justified on non-economic grounds, namely the need for proper organisation of the game because mid-season transfers could substantially alter the sporting strength and, therefore, the competition between teams in the course of a championship. ${ }^{22}$ Nevertheless, transfer windows in this particular case were found to be disproportionate and in breach of Article 45 of the Treaty because they were opened substantially longer for the players from outside the EU. ${ }^{23}$ The instruction from Annex I of the Commission Staff Working Document is that, had the transfer periods in Lehtonen been proportionate, they would have been justified not only under free movement law, but also under Articles 101(1) and 102 TFEU. ${ }^{24}$ Objectively justified sporting rules under internal market law satisfy the inherency test under competition law and vice-versa. ${ }^{25}$

The questions on the interpretation of EU competition law provisions were considered inadmissible due to the insufficient factual information provided by the referring national court. Similarly to AG Lenz in Bosman, AG Alber in Lehtonen considered the rule prima facie restrictive, but adopted the reasoning from $D L G$ to support the reasoning that necessary and proportionate rules may be saved from being labelled as restrictions. ${ }^{26}$

\footnotetext{
${ }^{19}$ Case C-250/92 Gøttrup-Klim e.a. Grovvareforeninger v Dansk Landbrugs Grovvareselskab AmbA (DLG) [1994] ECR I-5641.

${ }^{20}$ AG Lenz Opinion in Bosman, paras 269-270.

${ }^{21}$ Lehtonen, paras 47-50.

22 Ibid., paras 51-55.

${ }^{23}$ Ibid., paras 56-58. It was nevertheless left for the national court to ascertain whether there were any objective reasons that could justify this difference in the transfer windows (see para 59).

${ }^{24}$ European Commission, Commission Staff Working Document, Annex I, para 2.2.1.6.

${ }^{25}$ Pijetlovic 2015, pp 228-233.

${ }^{26}$ Opinion of Advocate General Alber, Case C-176/96 Jyri Lehtonen and Castors Canada Dry Namur-Braine $v$ Fédération Royale des Sociétés de Basket-ball and Ligue Belge-Belgische Liga, delivered on 22 June 1999, paras 107-108
} 
In Bernard, a trainee footballer was required to pay damages for the loss suffered by the club that trained him as a method of compensation for signing his first professional contract with another club and, consequently, breaching his contractual obligations. The Court utilised the obstacle approach to find that the compensation scheme in Bernard, while constituting neither a prohibition on signing a contract with a club in another Member State nor discrimination on the basis of nationality, nevertheless discourages the player from exercising his right of free movement by making it less attractive. ${ }^{27}$ Referring to the Bosman case by taking into account the considerable social importance of sporting activities, in particular football, in the EU, the Court accepted the objective of encouraging recruitment and training of young players as legitimate. ${ }^{28}$ The social importance of sport played a crucial role in legitimating this objective and it would probably not be accepted as such in (m)any other employment sectors. Unlike in Bosman, the compensation fees in Bernard were deemed capable of attaining the said objective. ${ }^{29}$ Thereafter, the Court referred for the first time to Article 165(1) TFEU; it set out the standard of application of the proportionality principle in the objective justification framework, according to which account must be taken of the specific characteristics of sport and its social and educational function. ${ }^{30}$ The same standard of application of proportionality test, it is submitted, applies in the interpretation and application of EU competition law to sport.

\subsection{Inherent rules: Deliège [2000]}

The concept of inherent rules originated in Deliège where the Court was asked to determine the compatibility with Article 56 (and Articles 101 and 102) TFEU of selection rules of the governing body for judo in Belgium limiting the number of participants in the high-level international competitions that do not involve national teams competing against each other. The question forwarded to the CJEU by the Tribunal de Première de Namur was whether it was contrary to those articles to 'require professional or semi-professional athletes, or persons aspiring to professional or semi-professional activity, to be authorised by their federation in order to be able to compete in international competition which does not involve national teams competing against each other'. ${ }^{31}$

The Court first dismissed the applicability of the purely sporting rule exception and recognised that unlike in Bosman the rules challenged in Deliège 'do not determine the conditions governing access to the labour market by professional sportsmen and do not contain nationality clauses limiting the number of nationals of other Member States who may participate in a competition'. ${ }^{32}$ The selection rules at issue in the main proceedings were, therefore, considered as non-discriminatory rules affecting the exercise of an economic activity rather than discriminatory market access rules. ${ }^{33}$ The Court proceeded to specify that the challenged rules

\footnotetext{
${ }^{27}$ Bernard, paras 23-37.

${ }^{28}$ Ibid. para 39.

${ }^{29}$ Ibid., paras 41-45.

${ }^{30}$ Ibid., para 40.

${ }^{31}$ Deliège, para 22.

32 Ibid., para 61.

${ }^{33}$ Under the 'Säger formula' this would have been enough to find a breach. Para 12 of Case C-76/90 Säger [1991] ECR I-4221 provides that Article 56 TFEU requires: 'not only the elimination of all discrimination
} 
could not in themselves constitute an obstacle on the freedom to provide services under Article 56 TFEU because limiting the number of participants is inherent in the conduct of an international high-level sports event, which necessarily involves certain selection rules or criteria being adopted'. ${ }^{34}$ The sport organisations must further be able to demonstrate that selection rules are based on objective criteria independent from the personal circumstances of the athletes. ${ }^{35}$

Although the Court did not explicitly mention that the inherent rules should be proportionate, such requirement follows from paragraph 65 of the judgment:

[...] the adoption, for the purposes of an international sports tournament, of one system for selecting participants rather than another must be based on a large number of considerations unconnected with the personal situation of any athlete, such as the nature, the organisation and the financing of the sport concerned.

Accordingly, the discriminatory rule would be considered disproportionate and would fail the inherency test. The preference of one system over another is left to sporting bodies and organisers $^{36}$ as long as the selection is made on the basis of objective factors unconnected with the athletes' personal situation. The proportionality of such a system is not questioned by the Court as it is deemed proportionate by default.

Only non-discriminatory rules that do not relate to market access can satisfy the inherency test under the free movement provisions. ${ }^{37}$ Therefore, the inherent rules exception includes rules that, based on legitimate objectives, ${ }^{38}$ do not constitute restrictions because they derive from the need, and their restrictive effects are, inherent in the organisation of sport, and are proportionate. The Commission in its Communication on Sport did not differentiate between competition and internal market law when it examined the compatibility of sporting rules with any EU law against the inherency and proportionality tests. ${ }^{39}$

The questions on the interpretation of EU competition law provisions in Deliège were similar to those expressed in Lehtonen in claiming them inadmissible due to insufficient factual information provided by the referring national court. AG Cosmas in Deliège referred to and followed the approach of AG Lenz in Bosman. ${ }^{40}$

\footnotetext{
against a person providing services on the ground of his nationality but also the abolition of any restriction, even if it applies without distinction to national providers of services and to those of other Member States, when it is liable to prohibit or otherwise impede the activities of provider of services established in another Member State where he lawfully provides similar services'. See on this point Miettinen and Parrish, Inherent Rules in EC Sports Law, presented at the Conference on Law and Popular Culture, Onati, Spain (June 2008).

${ }^{34}$ Deliège, para 64 (emphasis added).

35 Ibid., para 65.

${ }^{36}$ Ibid., paras 67-68.

${ }^{37}$ Miettinen and Parrish, Inherent Rules in EC Sports Law, presented at the Conference on Law and Popular Culture, Onati, Spain (June 2008).

${ }^{38}$ This criterion is specifically mentioned only in relation to competition provisions (in Meca-Medina case) but it applies to free movement as well. In Deliège the objective of the challenged rules was to make competitions workable by allowing only a limited number of selected participants.

${ }^{39}$ Communication from the Commission to the European Parliament, the Council, the European Economic and Social Committee, and the Committee of the Regions, Developing the European Dimension in Sport, COM (2011) 12 final, para 4.2 .

${ }^{40}$ Opinion of Advocate General Cosmas, Joined Cases C-51/96 and C-191/97 Christelle Deliège v. Ligue francophone de judo et disciplines associées ASBL [2000] ECR I-2549, delivered on 19 March 1999, paras 110 112.
} 


\subsection{Final remarks}

The distinctions made in internal market cases between purely sporting, inherent, and objectively justified rules do not apply in the analytical structure of competition law to organisational rules in sport. It is submitted that the different types of sporting rules identified in internal market law cases should all be dealt with under a single objective justification test, since it is able to accommodate every type of organisational rule and yet produce the same result. This would also bring clarity in cases where a legal claim is raised under both internal market and competition provisions of the Treaty. This judicial route naturally stems from the analytical framework provided by the Meca-Medina/Wouters test, discussed below in Section 7 , which mirrors the objective justification test under internal market law.

\section{Applicability of Articles 101 and 102 TFEU in the sporting sector}

Articles 101 and 102 TFEU provide a primary tool to control behaviour by undertakings that produce anti-competitive effects. The underlying objectives of these articles are of economic nature and include protecting undistorted competition on the market, achieving optimal allocation of resources, increasing consumer welfare and aiding in creation of the European internal market. ${ }^{41}$ During the various stages of integration the EU increasingly moved from a purely economic constitution designed for a market-oriented system to a constitutional model inclusive of wider socio-cultural concerns. This is reflected in both the application of EU competition articles by the EU institutions as well as in the development of EU sports law and policy. The application of antitrust law to organisational rules in the sporting sector inevitably raises questions on the interrelationship and balance between economic and social dimensions of the Union's policy and can become a relatively complex issue.

Article 101(1) TFEU prohibits agreements between undertakings, decisions by associations of undertakings or concerted practices, which are considered capable of affecting trade between Member States and that have as their object (i.e., subjectively intend) or effect (i.e., objectively cause $)^{42}$ the prevention, restriction, or distortion of competition within the internal market. Article 102 TFEU prohibits the abuse of market power by undertakings in a dominant position in one or more relevant markets. The thrust of this policy is not to prohibit the acquisition and existence of power per se, but is directed at controlling the unilateral behaviour of a dominant firm(s). In essence, three related enquiries must be conducted when determining the existence of an abuse of a dominant position, ${ }^{43}$ namely relevant market determination, dominance on the relevant market and establishing the abuse of that dominant position.

\footnotetext{
${ }^{41}$ For more details, see Craig and De Búrca 2011, p 959.

${ }^{42}$ For the concept of 'effects on trade', see Case C-56/65 Societe Technique Miniere v. Maschinenbau Ulm (STM) [1966] ECR 235, para 7; Case 56/64 Consten and Grundig [1966] ECR 299, para 27. See also European Commission, Guidelines on the effects on trade concept contained in Articles 81 and 82 of the Treaty [2004] OJ C 101/81.

${ }^{43}$ The Court has laid down the definition of the concept of dominant position in Case 27/76 United Brands $v$. Commission [1978] ERC 207, para 65.
} 
According to settled case law, Articles 101 and 102 TFEU are not mutually exclusive, but may be applied simultaneously. ${ }^{44}$ Already in its early judgment of Continental Can the CJEU held that Articles 101 and 102 TFEU seek to attain the same aim of maintaining effective competition within the common market. ${ }^{45}$ The agreements between two or more undertakings containing restrictive clauses might create or reinforce a position of dominance which is, or may become, subject to abuse. Such agreements may be deemed incompatible with both Article 101 and 102 TFEU.

It has been recognised that national and international sporting associations, clubs and independent athletes can constitute 'undertakings'. ${ }^{46}$ Sporting federations can, in addition, also constitute an 'association of undertakings' 47 or an 'association of associations of undertakings' ${ }^{48}$ Their rules can amount to 'agreements or decisions, ${ }^{49}$ distort competition within the relevant market and affect trade between Member States within the meaning of Articles 101 and 102 TFEU. ${ }^{50}$ Article 102 TFEU does not include the concept of 'association of undertakings', but applies to unilateral conduct of one or more dominant 'undertakings'. The General Court has held that even where a sports federation, such as FIFA, is not active on a particular market, it may be considered an 'undertaking' under Article 102 TFEU to the extent

\footnotetext{
${ }^{44}$ See Case 85/76 Hoffmann-La Roche [1979] ECR 461, para 116; Case 66/86 Ahmed Saeed Flugreisen and Silver Line Reisebüro GmbH v Zentrale zur Bekämpfung unlauteren Wettbewerbs e.V. [1989] ECR 803, para 37; Joined Cases C-395/96 P and C-396/96 P Compagnie Maritime Belge Transports SA, Compagnie Maritime Belge SA and Dafra-Lines A/S v Commission [2000] ECR I-1365, para 33.

${ }^{45}$ Case 6/72 Europemballage Corporation and Continental Can Company Inc. v. Commission [1973] ECR 215, para 11; See also Case T-51/89 Tetra Pack Rausing SA v. Commission [1990] ECR II-309, para 22.

${ }^{46}$ For national and international sporting associations as undertakings see Case T-193/02 Laurent Piau v. Commission [2005] ECR II-0209, paras 69-72; Commission Decision in COMP IV/37.806 - ENIC/UEFA, unpublished decision of 27 June 2002, para 25; Opinion of Advocate General Lenz in Bosman, points 255 et seq; Commission Decision in Cases 33.384 and 33.378 — Distribution of package tours during the 1990 World Cup [1992] OJ L 326/31, paras 47 and 52-53. For individual athletes as undertakings see Deliège, paras 56-57. According to AG Lenz in Bosman, para 263, football players employed by a football club do not constitute undertakings, as they are workers and not providers of services. Commission Staff Working Document, The EU and Sport: Background and Context, Accompanying Document to the White Paper on Sport, COM (2007) 391 final, Annex I, para 2.1.3 clarifies that 'even if athletes are employed by a sport club, they may be considered undertakings insofar as they carry out economic activities independent thereof, e.g., by entering into sponsoring agreements'.

47 See Piau, paras 69-72, where the General Court held that '69. [...] FIFA's members are national associations, which are groupings of football clubs for which the practice of football is an economic activity. These football clubs are therefore undertakings within the meaning of Article [101 TFEU] and the national associations grouping them together are associations of undertakings within the meaning of that provision. 70. The fact that the national associations are groupings of 'amateur' clubs, alongside 'professional' clubs, is not capable of calling that assessment into question.[...] 72. Since the national associations constitute associations of undertakings and also, by virtue of the economic activities that they pursue, undertakings, FIFA, an association grouping together national associations, also constitutes an association of undertakings within the meaning of Article [101 TFEU].' See also Opinion of AG Lenz in Bosman, paras 255-257; Commission Decision in Case COMP/C.2-37.398 - Joint Selling of the Commercial Rights of the UEFA Champions League [2003] OJ L $291 / 25$

${ }^{48}$ UEFA Champions League, para 106.

${ }^{49}$ Piau, para 75. Rules drawn up unilaterally by sporting associations consisting of undertakings will usually constitute decisions by an association of undertakings (see ENIC/UEFA, para 26, for a rule drawn up by the UEFA Executive Committee, and Meca-Medina, para 45 for a rule drawn up by the International Olympic Committee and implemented by the International Swimming Federation).

${ }^{50}$ For general guidance see European Commission, Guidelines on the effect of trade concept contained in Articles 81 and 82 of the Treaty [2004] OJ C 101/7.
} 
that it represents the emanation of its members that are active on that market. ${ }^{51}$ Furthermore, when they directly engage in an economic activity, sporting federations usually acquire a status of an undertaking in a monopolistic position, ${ }^{52}$ whereas clubs organised in a league may be held collectively dominant within the meaning of Article 102 as interpreted by the relevant case law. ${ }^{53}$ Rules adopted by international sporting organisations would normally affect trade between Member States due to their scope of application. Additionally, rules of national sports associations usually affect only the territory of their respective country, but in the light of the high degree of internationalisation and mobility in professional sport, those rules may also affect trade between Member States. ${ }^{54}$

The scope of Articles 101(1) and 102 TFEU is very broad since no actual and direct effect on trade is required and prima facie any agreement and any abuse of a dominant position may be covered by these provisions. However, there are a number of exceptions available. Two exceptions that are of particular importance for the topic of this chapter are the economic efficiency defence and the judicially developed ancillary restraints doctrine.

\section{Exceptions under Articles 101 and 102 TFEU}

\subsection{Economic efficiency defence under Articles 101(3) and 102 TFEU}

Agreements, decisions or practices that are incompatible with Article 101(1), but satisfy the conditions under Article 101(3) of the Treaty, are valid and enforceable with no prior decision to that effect being required. ${ }^{55}$ The rationale behind this provision is that certain agreements may have both pro-competitive and anti-competitive features. The dual nature of economic effects usually involves complex economic analysis weighting the beneficial and harmful effects in order to determine whether the agreement qualifies for the exemption. Accordingly, those agreements, decisions or practices that fulfil the four conditions outlined in this provision would benefit from an exemption. Two positive conditions state that an agreement must improve the production or distribution of goods or promote technical or economic progress, and at the same time allow consumers a fair share of the resulting benefits. Two negative conditions require that an agreement cannot contain any restrictions that are not essential to the attainment of the objectives under agreement (i.e. disproportionate restrictions) and cannot lead to the elimination of competition in respect of a substantial part of the product in question. Balancing of anti-competitive and pro-competitive effects is conducted exclusively within the framework

\footnotetext{
${ }^{51}$ Piau, paras 112 and 116.

${ }^{52}$ Commission Staff Working Document, Annex I, para 2.1.4 recognises that: 'sports associations usually have practical monopolies in a given sport and may thus normally be considered dominant in the market of the organisation of sport events under Article [102] EC.'

${ }^{53}$ For discussion on the concept of collective dominance in the sporting context see Piau, paras 113-115; AG Lenz Opinion in Bosman, para 285.

${ }^{54}$ For more on the application of basic elements of EU competition law in sporting sector, see Commission Staff Working Document, Annex I, discussed below in Section 6.

55 Council Regulation (EC) No 1/2003 of 16 December 2002 on the implementation of the rules on competition laid down in Articles 81 and 82 of the Treaty [2003] OJ L 1/1, art 1 (2).
} 
laid down by Article 101(3), ${ }^{56}$ and there is no scope in this provision for non-competition arguments that cannot be translated into economic efficiencies. ${ }^{57}$ The approach of the EU Commission is that under Article 101(3), public policy objectives may be taken into account only if they can be subsumed under one of its four conditions, ${ }^{58}$ so as a supplement to economic benefits that the agreement generates. ${ }^{59}$

A company holding a dominant position may benefit from an exemption under Article 101(3) of the Treaty when its conditions are fulfilled. ${ }^{60}$ In the Piau case decided in the sporting context, the General Court held that if the conduct of a dominant company satisfies all the conditions of Article 101(3) such conduct should not be classified as an abuse under Article 102 of the Treaty. ${ }^{61}$

Unlike Article 101 TFEU, Article 102 TFEU does not contain an exemption provision. However, the Commission outlined in its 2005 Discussion Paper the conditions under which a dominant company may also rely on the efficiency defence in cases of abusive exclusionary conduct. These conditions, which reproduce the four cumulative criteria of Article 101(3) TFEU, were later confirmed in the Commission Guidance reflecting the overall reform and the uniform approach towards Article 102 TFEU and shifting the focus from the form-based towards a more effects-based analysis. ${ }^{62}$ By mirroring the cartel exemption provision, the efficiency defence amounts to a functional and analytical equivalent of Article 101(3) TFEU in the framework of Article 102 TFEU.

\footnotetext{
${ }^{56}$ See European Commission, Guidelines on application of Article 81 (3) of the Treaty [2004] OJ C 101/97, para 11; European Commission, Guidelines on the applicability of Article 101 of the Treaty on the Functioning of the European Union to horizontal co-operation agreements [2011] OJ C11/1, para 20. See also Case T-65/98 Van den Bergh Foods [2003] ECR II-4653, para 107; Case T-112/99 Métropole télévision (M6) and others [2001] ECR II-2459, para 74, where the General Court held that it is only in the framework of Article 101(3) that the pro- and anti-competitive aspects of a restriction may be weighed.

${ }^{57}$ See also Semmelmann 2008, p 15. The Commission has accepted arguments on the basis of environmental protection in Case IV/F 1/36/718 - CECED [2000] OJ L 187/47. In Case 26/76 Metro (I) [1977] ECR 1875, para 43, the Court has accepted that 'the establishment of supply forecasts for a reasonable period constitutes a stabilising factor with regard to the provision of employment which, since it improves general conditions of production, [...] comes within the framework of the objectives to which reference may be had pursuant to Article [101(3)]'. The stabilising effect of an agreement on employment may translate into cost savings and other efficiency gains.

${ }^{58}$ European Commission, Guidelines on the application of Article 81 (3) of the Treaty [2004] OJ C 101/97, para 42. So far, the other policy objectives have been considered under the first condition. See also Commission White Paper on Modernisation of the rules implementing Articles 81 and 82 of the EC Treaty, Commission Programme No 99/027 1999/OJ C 132/1, which in para 56 states that Article 101 (3) is meant to 'provide a legal framework for the economic assessment of restrictive practices and not to allow the application of the competition rules to be set aside because of political considerations'.

${ }^{59}$ See Section 4.2 below.

${ }^{60}$ European Commission, Guidelines on the application of Article 81 (3) of the Treaty [2004] OJ C 101/97, pp

97-118, para 106.

${ }^{61}$ Piau, para 119.

${ }^{62}$ European Commission, Guidance on the Commission's enforcement priorities in applying Article 82 of the EC Treaty to abusive exclusionary conduct by dominant undertakings [2009] OJ C 45/7, para 30.
} 


\subsection{Regulatory ancillarity}

Ancillary restraints (restrictions on competition that are directly related and objectively necessary for the implementation of the main non-restrictive transaction and are proportionate to it) fall outside of the ambit of Article 101(1) TFEU. ${ }^{63}$ The STM, Metro and DLG cases ${ }^{64}$ involved 'commercial ancillarity' restraints because the restrictions on competition were ancillary to a legitimate commercial purpose. ${ }^{65}$

The exception that is relevant for organisational rules in sport was introduced by the CJEU in Wouters $^{66}$ and it was characterised by Monti as a 'European-style rule of reason' ${ }^{67}$ and by Whish, perhaps more accurately, as a 'regulatory ancillarity' ${ }^{68}$ The judgment does not really introduce the rule of reason in Article 101(1) because balancing of the pro- and anti-competitive effects of restrictions involves economic arguments on both sides, whereas Wouters introduces a balancing between EU competition law objectives and non-economic public interests that do not necessarily need to be a part of the Union's objectives. Accordingly, certain types of agreements or decisions that restrict the commercial behaviour of undertakings do not violate the prohibition in Article 101(1) TFEU, if, because of their context and objectives, the restrictions in those agreements or decisions are inherent and proportionate to the realisation of non-competition objectives. ${ }^{69}$ In the case law on regulatory ancillarity ${ }^{70}$ the exception was applied only in cases of regulatory restrictions imposed by collective private bodies (and public legal persons when engaging in economic activity and not exercising powers which are typical of public authority) in the public interest, whether at national, European or global level. The Court has so far applied this framework only to rules having a public law character and deemed necessary for the proper organisation and ethical conduct of a certain profession. It is submitted that these facts do not imply that the framework developed under that case law cannot be used to accommodate other kinds of non-competition objectives, in particular those under policylinking clauses of the Treaty, the importance of which has been enhanced by the Lisbon amendments. ${ }^{71}$ To allow a reliance on the public interest defence for agreements concluded by private parties that do not derive their powers from public laws, especially private collective bodies such as the Fédération Internationale de Football Association (FIFA) and UEFA, is necessary in an area where no responsible public authority vested with powers to enforce the

\footnotetext{
${ }^{63}$ European Commission, Guidelines on the Application of Article 81 (3) of the Treaty [2004] OJ C 101/97, paras 28-31; Métropole, para 104.

${ }^{64}$ Case C-56/65 Société Technique Minière (L.T.M.) v Maschinenbau Ulm GmbH (M.B.U.) [1966] ECR 235; Case 26/76 Metro SB-Großmärkte GmbH \& Co. KG v Commission of the European Communities [1977] ECR 1875; Case C-250/92 DLG [1994] ECR I-5641.

${ }^{65}$ As termed by Whish 2009, p 126.

${ }^{66}$ Wouters, para 97.

${ }^{67}$ Monti 2002, pp 1087-1088.

${ }^{68}$ Whish 2009, p 126.

${ }^{69}$ Wouters, para 97; Meca-Medina, para 42.

${ }^{70}$ Wouters, Meca-Medina, Case C-1/12 Ordem dos Técnicos Oficiais de Contas v Autoridade da Concorrência (OTOC) [2013], and Case C-136/12 Consiglio nazionale dei geologi v Autorità garante della concorrenza e del mercato and Autorità garante della concorrenza e del mercato v Consiglio nazionale dei geologi (CNG) [2013]. See also Commission decision in ENIC/UEFA.

${ }^{71}$ Pijetlovic 2015, p 153. The EU for the first time has a duty to mainstream the policy objectives under Article 7 TFEU after the Lisbon amendments: 'The Union shall ensure consistency between its policies and activities, taking all of its objectives into account and in accordance with the principle of conferral of powers'.
} 
laws protecting those public interests exists. ${ }^{72}$ It represents a constitutional fine-tuning of the Union's competition law in view of the increase in private governance and self-regulation of certain sectors and the corresponding decrease in the private/public divide in EU law.

It is worth mentioning that in the ENIC case concerning the UEFA rule prohibiting multiple ownership of clubs the Commission applied the Wouters test and recognised its necessity. The foregoing considerations present one of the reasons why the principle of convergence ought to be formally adopted within competition and internal market provisions to the extent possible. ${ }^{73}$ The Court has anyhow made some competition decisions on the basis of single market considerations, which at that time, due to misunderstandings and lack of any references to convergence, attracted a lot of criticism. ${ }^{74}$

The framework established by Wouters can accommodate any other policy objectives in accordance with Article 7 TFEU and, at the same time, stay faithful to the already established and persistently defended paradigms that balancing of anti-competitive and pro-competitive effects is conducted exclusively within the framework of Article 101(3) TFEU. Only economic efficiencies are to be taken into account in the exemption provision which includes public policy objectives that can be translated into an economic efficiency argument. ${ }^{75}$

Namely, an agreement or decision that restricts competition, but genuinely pursues a public policy objective under some of the policy-linking clauses ${ }^{76}$ or outside their scope ${ }^{77}$ that is not protected by a public regulation, ${ }^{78}$ and that fulfils the Wouters criteria could thus escape the scope of Article 101(1) TFEU. Should the outcome of the Wouters test be different, the agreement or decision would have to satisfy the four conditions of Article 101(3). If the public policy objective that it pursues can be transposed into economic benefits, it should be taken into account also in the framework of the exemption provision, although it is likely to fail the indispensability requirement in the cases where it already failed to satisfy the proportionality under Wouters. This is the true face of the European-style rule of reason and to interpret the exemption provision as suitable for purely non-competition arguments would have the effect of completely blurring the distinction between the different paragraphs of Article 101. ${ }^{79}$

Under Article 102 TFEU, the EU Courts and the Commission normally use the concept of objective justification coupled with the proportionality test ${ }^{80}$ instead of the ancillary restraints

\footnotetext{
${ }^{72}$ However, the General Court held that where there is public authority with powers, for example, in relation to product safety, it is not for private undertakings to take the initiative to eliminate the products which are not safe. See Case T-30/89 Hilti v Commission [1991] ECR II-1439, para 118.

${ }^{73}$ Pijetlovic 2015, pp 215-235.

${ }^{74}$ See, for example, discussion on Consten and Grundig, Jones and Sufrin 2011, pp 204-209.

${ }^{75}$ Monti 2002, p 1057 and pp 1090-1091; Faull and Nikpay 2007, para 3.406; Case T-17/98 Matra Hatchette v Commission [1994] ECR II-595, para 139; Cases C-403 and 429/08 Premier League LTD v QC Leisure and Murphy v Media Protection Services LTD [2011] ECR I-9083.

${ }^{76}$ Such as clauses related to environmental protection in Article 11 TFEU, consumer protection in Article 12 TFEU, achieving high level of employment in Article 147 (2) TFEU, respect for cultural diversities in Article 167 (4) TFEU, health protection in Article 168 (1) TFEU, competitiveness of the Union's industry in Article 173 (3) TFEU, and regional development under Article 175 TFEU.

77 See Wouters, Meca-Medina, and Gøttrup-Klim.

${ }^{78}$ Hilti, para 118.

${ }^{79}$ Pijetlovic 2015, p 156.

${ }^{80}$ Case T-65/89 BPB [1993] ECR II-00389, para 94; Hilti, paras 102-119; Case 311/84 Centre Belge d'Etudes du Marché-Télémarketing (CBEM) v. CLT SA [1985] ECR 3261, para 26.
} 
doctrine, although both concepts perform exactly the same function. It would appear from the decisional practice of the Commission, as well as from the Commission's Guidance, ${ }^{81}$ that objective justifications may include non-economic objectives and amount to an equivalent of public policy justification under Article 101(1) TFEU. A dominant undertaking that engages in an abusive, but objectively justified and proportionate conduct will be, as a matter of technicality, considered as not having committed an abuse in the first place. ${ }^{82}$

It is submitted that the objective justification defence has been replaced by the Wouters test when applying Article 102 TFEU to regulatory acts of collective bodies that pursue a public policy interest. With regard to organisational rules in sport, this submission is no longer debatable. The Commission in its Staff Working Document was unequivocal that MecaMedina, that fully embraced Wouters test in regard to Article 101(1) TFEU, provides guidance as regards the methodological approach towards assessing a sporting rule under both Articles 101 and 102 TFEU. $^{83}$

\section{Commission investigation in FIA [2001] and Court's decision in MOTOE [2008]}

A case concerning the conflict of interest between the regulatory and commercial functions of a sport association involved the Fédération Internationale d'Automobile (FIA), the international association for motor sport. FIA is the organiser and promoter of motor sport championships, including Formula One. It issued licences to any party wishing to participate in international motor sport events authorised by FIA, including track owners, vehicle manufacturers, organisers of motor sport events and drivers. License holders were allowed to organise or enter only those events authorised by FIA. Entering or organising events not authorised by FIA would lead to the loss of their license and the end of any commercial activity in motor sport. This way, FIA was able to exercise control over everyone and everything needed to stage a rival championship that could compete with FIA's events.

The Commission found evidence that the competing GTR Organisation was forced out of the market by FIA's rules and that the GTR series were replaced by the FIA GT Championship. Furthermore, FIA claimed media rights to all events incorporating the FIA name, which were then transferred to International Sportsworld Communicators (ISC). In addition, Formula One teams were forced by the terms of the tripartite Concorde Agreement to assign all broadcasting rights in the Formula One championship to FIA, which were later transferred to Formula One Administration Ltd (FOA), a commercial rights holder. The same agreement also prevented Formula One teams from racing in any other series comparable to Formula One for a considerably long period of time. The promoters' rights were taken directly by FOA, which had been given the power by the FIA to determine who can and cannot be a promoter of a grand prix. It is also interesting to note that the vice-president of FIA, Bernie Ecclestone, was in control of both FOA and ISC.

\footnotetext{
${ }^{81}$ European Commission, Guidance on the Commission's enforcement priorities in applying Article 82 of the EC Treaty to abusive exclusionary conduct by dominant undertakings [2009] OJ C 45/7.

${ }^{82}$ On the last point see the AG Jacobs Opinion in Case C-53/03 Synetairismos Farmakopoion Aitolias \& Akarnanias (Syfait) and Others $v$. GlaxoSmithKline plc and GlaxoSmithKline AEVE, formerly Glaxowellcome AEVE [2005] ECR I-04609, delivered on 28 October 2004, para 72.

${ }^{83}$ Commission Staff Working Document, Annex I, para 2.1.1; Case C-250/92 DLG [1994] ECR I-5641.
} 
An agreement between FOA and a number of broadcasters and promoters involved in the Formula One championship was reinforcing the existing hurdles for those who wished to stage a series competing with Formula One. The promoters' contracts prevented circuits used for Formula One races from being used for competing races, while the agreements with broadcasters placed a massive financial penalty, ranging from between $33 \%$ to $50 \%$ of the price paid, if they televised anything deemed by FOA to be a competitive threat to Formula One. ${ }^{84}$ In 1999, the Commission issued a Statement of Objections. It came to the preliminary conclusion that the rules described were contrary to Articles 101(1) and 102 TFEU as they gave FIA control to block the organisation of races that competed with the events FIA promoted or organised, in particular Formula One from which it derived the biggest commercial benefit. The Commission also objected to certain terms of the contracts between the FOA and broadcasters. Finally, the Commission objected to FIA rules according to which FIA automatically acquired media rights to all motor sport events, even if they were promoted by a different promoter. The core of all of the objections was directed at the conflict between the FIA's legitimate role as the regulator of international motor sport and its commercial interests. ${ }^{85}$

In 2001 the Commission closed the case after reaching a settlement with FIA's president Max Mosley and the CEO of FOA Bernie Ecclestone. The settlement provided that FIA would:

limit its role to that of a sport regulator without influence over the commercial exploitation of the sport and thus removing any conflict of interest (through the appointment by FIA of a 'commercial rights holder' for 100 years in exchange for a one-off fee); guarantee access to motor sport to any racing organisation and to no longer prevent teams to participate in and circuit owners to organize other races provided the requisite safety standards are met; waive its TV rights or transfer them to the promoters concerned; and remove the anticompetitive clauses from the agreements between FOA and broadcasters. ${ }^{86}$

Later in 2001, after consultation with all the interested parties, the Commission closed its investigation in the FIA case satisfied that the agreed amendments will alleviate competition concerns. ${ }^{87}$ In 2003 it ended its monitoring of FIA's compliance with the 2001 settlement. ${ }^{88}$

It is important to compare this case with MOTOE in which the restrictions on competition were enabled through the grant of special or exclusive rights by the Greek government. In MOTOE, Article 49 of the Greek Road Traffic Code provided that a license to organise motorcycling events would be issued to the organisers by the Minister for Public Order or the authorities empowered by him only after the organiser secures the consent from the official representative of the Fédération Internationale de Motocyclisme (the International Motorcycling Federation)

\footnotetext{
${ }^{84}$ European Commission, Commission opens formal proceedings into Formula One and other international motor racing series, IP/99/434 (Brussels 30 June 1999).

${ }^{85}$ European Commission, Commission welcomes progress towards resolving the long-running FIA/Formula One case, IP/01/120 (Brussels 26 January 2001).

${ }^{86}$ Commission, Staff Working Document, Annex I, para 2.2.2.1.

${ }^{87}$ European Commission, Commission closes its investigation into Formula One and other four-wheel motor sports, IP/01/1523 (Brussels 30 October 2001).

${ }^{88}$ European Commission, Commission ends monitoring of FIA/Formula One compliance with 2001 settlement, IP/03/1491 (Brussels 31 October 2003).
} 
in Greece. Accordingly, the power to grant consent for the organisation of motorcycling events was given to ELPA (Elliniki Leskhi Aftokinitou kai Periigiseon - Automobile and Touring Club of Greece), a legal person and a non-profit association which organized the same kinds of events in Greece. MOTOE (Greek Motorcycling Federation) planned to organise a motorcycling competition in Greece, but ELPA rejected its application for no objective reason and, therefore, failed to obtain authorisation from the competent ministry. Subsequently, MOTOE claimed pecuniary damages from the government in the Greek national court relying on Articles 102 and 106(1) TFEU. Article 49 of the Greeks Road Traffic Code conferred on ELPA a position of monopoly power over the organisation of motorcycle events in Greece which as such does not breach Article 102 of the Treaty unless that power is being abused. MOTOE claimed that ELPA abused its monopolistic position by refusing to grant the consent needed for authorisation of its planned event.

There was no doubt that ELPA was dominant on the markets for the organisation of motorcycling events and for their commercial exploitation by means of sponsorship, advertising and insurance contracts. Granting special or exclusive rights to an undertaking to control whether and under which conditions other undertakings can gain access and engage in activities on the relevant market entails such conclusion. ELPA's monopoly to grant the necessary consent was statutory and, therefore, the examination of Article 106 TFEU was needed. The classification of ELPA as an undertaking entrusted with the operation of 'services of general economic interests' for the purposes of Article 106(2) TFEU was dismissed on the following ground: the undertaking's economic activities related to the organisation and commercial exploitation of motorcycling events were not conferred by an act of entrustment by the public authority, an element needed for the application of this provision. The power to grant consent to applications for authorisation to organise motorcycling events, although stemming from an act of public authority, could not be classified as an economic activity. Consequently, Article 106(2) TFEU was held inapplicable to this part of ELPA's activities. ${ }^{89}$

The Court then turned its attention to Article 106(1) TFEU in conjunction with Article 102 TFEU. The mere creation or reinforcement of a dominant position through the grant of special or exclusive rights within the meaning of Article 106(1) TFEU was not in itself considered incompatible with Article 102 TFEU. However, it held that:

a Member State will be in breach of the prohibitions laid down by those two provisions if the undertaking in question, merely by exercising the special or exclusive rights conferred upon it, is led to abuse its dominant position or where such rights are liable to create a situation in which that undertaking is led to commit such abuses (Höfner and Elser, cited above, paragraph 29; ERT, cited above, paragraph 37; Case C-179/90 Merci convenzionali porto di Genova [1991] ECR I-5889, paragraphs 16 and 17; and Case C-323/93 Centre d'insémination de la Crespelle [1994] ECR I-5077, paragraph 18). In this respect, it is not necessary that any abuse should actually occur (see, to that effect, Case C-55/96 Job Centre [1997] ECR I-7119, paragraph 36). In any event, Articles [102 TFEU and 106(1) TFEU] are infringed where a measure imputable to a Member State, and in particular a measure by which a Member State confers special or exclusive rights within the meaning of Article [106(1) TFEU], gives rise to a risk of an abuse of a dominant position (see, to that effect, ERT, cited above, paragraph 37; Merci convenzionali

\footnotetext{
${ }^{89}$ MOTOE, paras 44-47.
} 
porto di Genova, cited above, paragraph 17; and Case C-380/05 Centro Europa 7 [2008] ECR I-0000, paragraph 60). ${ }^{90}$

The judgment in MOTOE, paragraphs 49 and 50, clearly indicates that the Court will consider Article 106(1) in conjunction with Article 102 breached where the dominant position creates the mere possibility for an undertaking to commit an abuse. The concept of abuse is interpreted broadly, covering 'a risk of an abuse of a dominant position'. The key question is the discretion that a Member State leaves for the regulatory bodies to abuse the conferred powers. Should an undertaking be under an obligation to engage in abusive practices, the Member State is to be held responsible for such practices, and conversely, if an undertaking has discretion not to abuse its special powers the Member State will not be held responsible for the committed abuses. ${ }^{91}$ This is reminiscent of the approach to oligopolistic markets and even to a substantive assessment of concentrations than to the well-established approach to Article 102 TFEU under which abuse has to take place in order to find violation. On the facts of the case, ELPA was the sole organizer of motorcycling events and, in addition, was in charge of giving consent to other undertakings to organise and commercially exploit motorcycling events. Such powers granted to ELPA an apparent advantageous position over its competitors, whereby it could restrict access to the relevant market for all other operators. ${ }^{92}$

The final word of the Court was that:

[...] a rule, which gives a legal person such as ELPA the power to give consent to applications for authorisation to organise motorcycling events without that power being made subject by that rule to restrictions, obligations and review, could lead the legal person entrusted with giving that consent to distort competition by favouring events which it organises or those in whose organisation it participates. [...]. ${ }^{93}$

Although paragraphs 49 and 50 considered the mere existence of a conflict of interest in breach of Article 106(1) in conjunction with 102, this breach could have been avoided if the power granted to ELPA were subject to an appropriate standard of control. In this case there was no such control mechanism upon ELPA's activities and Greece lost the case. Nevertheless, as concerns the more general principle derived from the MOTOE judgment, a justification for the inevitable abuse could be found. Miettinen concluded that, 'as a consequence of MOTOE, it could be argued that since all undertakings that are endowed with regulatory powers are placed in a dominant position, regardless of whether they abuse that position they must be subject to 'restrictions, obligations and review.",94

Much like MOTOE, FIA was a case of sporting 'conflict of interest' examined under the TFEU competition rules. In both cases the central issue was the conflation of regulatory and commercial functions in one body, which ultimately led to the blocking of competing

\footnotetext{
${ }^{90}$ Ibid., paras 49 and 50.

${ }^{91}$ For an analytical comment on MOTOE that details this point see Miettinen 2009, pp 137-149.

${ }^{92}$ MOTOE, para 51. In Case C-41/90 Höfner and Elser v. Macrotron [1991] ECR I-1979, para 29, it was held that the state measure within the meaning of Article 106 (1) will be unlawful where by exercising exclusive rights conferred on it an undertaking cannot avoid abusing dominant position. In Case C-203/96 Dusseldorp [1998] ECR I-4075, para 61, the Court held that Article 106 (1) in conjunction with Article 102 will be breached where the Member State 'adopts any law, regulation or administrative provision which enables an undertaking on which it has conferred rights to abuse its dominant position'.

${ }^{93}$ MOTOE, para 51.

${ }^{94}$ Miettinen 2009, p 147.
} 
organisations and preventing market access. Both cases involved sporting bodies which abused organisational rules to protect their private interests rather than acting on behalf of public interests. None of the cases involved the specificity of sport in any form. Unlike MOTOE, in FIA there was no element of state involvement, as the powers delegated stemmed not from an act of a public authority, but from its own rules and a web of private agreements. Whereas in $M O T O E$ the requirement on the Member State was to create a system of safeguards against abuse (by ELPA's refusal to grant the consent necessary for the issuance of license) of the dominant position it enabled, in FIA the mere fact that the body was issuing licenses was not a problem. Rather, it was the restrictions on competition that those licenses entailed under the disputed rules. ${ }^{95}$ The safeguard against an unjustified refusal of licenses as in the FIA case was the obligation to insert a new clause ensuring that a legal recourse against FIA's decisions would be available not only within their organizational structure, but also before national courts.

\section{Commission decisions in Mouscron [1999] and ENIC [2002]}

Several years prior to the seminal Meca-Medina judgement, in $E N I C^{96}$ and in the unpublished Mouscron decision ${ }^{97}$ the Commission directly applied paragraph 97 of Wouters in its positive assessment of the UEFA rule on multi-club ownership and the 'home and away rule', respectively.

In Mouscron, the organisation of a sport on a territorial basis was brought into question. The UEFA 'home and away rule', according to which each club must play its home matches at its own ground, was challenged on the basis of Article 102 by the French Communauté Urbaine de Lille after UEFA refused to allow the Belgian club Excelsior Mouscron to play its home match against the French club Metz in Lille. The Commission rejected the complaint; it considered the rule indispensable for the organisation of national and international competitions in view of ensuring equality of chances between clubs. Furthermore, the rule was also found to be proportionate.

In ENIC ethical considerations on multi-club ownership prevented the Commission to find the rule restrictive under competition law and, instead, it was considered 'inherent'. Specifically, the rule stated that no two or more clubs participating in a UEFA club competition may be directly or indirectly controlled by the same entity or managed by the same person. According to the Commission the rule was designed to 'ensure the uncertainty of the outcome and to

\footnotetext{
95 This is evident from the Statement of Objections and from the section 6 of the Notice (Notice published pursuant to Article 19 (3) of Council Regulation No 17 concerning Cases COMP/35.163 - Notification of FIA Regulations, COMP/36.638 - Notification by FIA/FOA of agreements relating to the FIA Formula One World Championship, COMP/36.776 — GTR/FIA \& others [2001] OJ C 169/5), which says that 'the notified agreements as amended will remove those barriers which had prevented in the past the use of FIA licensed products and circuits or the participation of FIA licensees in different disciplines or in competing events in the same discipline. The proposed changes to the notified agreements will, for example, result in the availability of racetracks in Europe for rival series to use, even if these circuits already host FIA Formula One championship events.'

${ }^{96}$ ENIC/UEFA. See also European Commission, Commission Closes Investigation into UEFA Rule on Multiple Ownership of Football Clubs, IP/02/942 (Brussels 27 June 2002).

${ }^{97}$ Case COMP/E3/36.85 — Lille/UEFA (the Mouscron case), unpublished Commission Decision of 3 December 1999; European Commission, Limits to Application of Treaty Competition Rules to Sport: Commission Gives Clear Signal, IP/99/965 (Brussels 9 December 1999); See also European Commission, XXIXth Report on Competition Policy 1999, pp 166-167.
} 
guarantee that the consumer has the perception that the games played represent honest sporting competitions [...] ${ }^{98}$ Additionally, the public's perception of integrity is an essential precondition to keep the consumer's confidence and interest, as well as marketability of sporting competitions. Otherwise, as an inevitable consequence over time, '[c]lubs would be less capable of extracting value from ancillary activities and investment in clubs would lose value'. ${ }^{99}$ The rule was held proportionate, since it did not prevent capital investment in football clubs, but merely prohibited more than one club with the same ownership, management or control from participating in the same UEFA competition. ${ }^{100}$

\section{C-519/04 Meca-Medina [2006]: the ultimate test for regulatory rules in sport}

All judgements of the CJEU prior to and after Meca-Medina that dealt with organisational rules in sport were taken solely under provisions on freedom of movement of workers and services. The first time that the Court directly addressed the application of competition provisions to regulatory rules in sport was in the Meca-Medina judgment of 2006. This decision confirmed the applicability of the analytical structure developed in Wouters to regulatory rules in sport. For this reason, the case deserves special attention.

\subsection{Factual background}

The case involved two professional swimmers who were found to have breached the sport's anti-doping rules adopted by the International Olympic Committee (IOC). They tested positive for nandrolone and were suspended for a period of four years by the Doping Panel of the International Swimming Federation that implemented the rules for their discipline. ${ }^{101}$ Contesting the anti-doping rules, the applicants asserted that they were in breach of Articles 101 and 102, and Article 56 on freedom to provide services:

[...] First of all, the fixing of the limit at $2 \mathrm{ng} / \mathrm{ml}$ is a concerted practice between the IOC and the 27 laboratories accredited by it. That limit is scientifically unfounded and can lead to the exclusion of innocent or merely negligent athletes. In the applicants' case, the excesses could have been the result of the consumption of a meal containing boar meat. Also, the IOC's adoption of a mechanism of strict liability and the establishment of tribunals responsible for the settlement of sports disputes by arbitration (the CAS and the ICAS) which are insufficiently independent of the IOC strengthens the anti-competitive nature of that limit. $[\ldots] .{ }^{102}$

\footnotetext{
${ }^{98} \mathrm{ENIC/UEFA, \text {para } 2 8 .}$

${ }^{99}$ Ibid., para 32.

100 Ibid., para 34.

101 The appeal against the suspension was first launched before the Court of Arbitration for Sport which confirmed the decision of the doping panel but later, when scientific experiments showed that nandrolone's metabolites can be produced endogenously by the human body at a level which may exceed the accepted limit when certain foods have been consumed, they reduced the sanctions to two years. In 2001, however, the applicants launched the complaint with the Commission whose decision they appealed against before the General Court, and finally the decision of the General Court was brought before the Court.

${ }^{102}$ Meca-Medina, paras 16-17.
} 


\subsection{Judgment of the Court: scope of the Treaty}

As a starting point the Court reiterated the principles developed in its previous case law. The orthodox rule that originated in paragraph 4 of Walrave provides that 'sport is subject to Community law only in so far as it constitutes an economic activity [...]'. ${ }^{103}$ Rules of 'purely sporting' interest having nothing to do with economic activity are excluded from the scope of the Treaty. ${ }^{104}$ The Court cited paragraphs 14 and 15 of Donà and held that freedom of movement provisions 'do not preclude rules or practices justified on non-economic grounds which relate to the particular nature and context of certain sporting events,' and are limited to their proper objective. ${ }^{105}$ Such a restriction on the scope of the freedom of movement provisions 'cannot be relied upon to exclude the whole of a sporting activity from the scope of the Treaty'. ${ }^{106}$ This was established in identical language 11 years before Meca-Medina by the Court's answer to the arguments raised by the German Government in Bosman that sport such as football is not an economic activity, that it is akin to culture and should be treated as such, and to UEFA's arguments in that case calling for an exception due to the particular nature of sport. The Court said it was addressing 'the question of application of Article [45 TFEU] to rules laid down by sporting associations' that UEFA and German government were contesting. ${ }^{107}$

In Meca-Medina and Bosman the Court stated the obvious: the sporting activity in question and sport regulations cannot altogether be excluded from the scope of the Treaty. The restriction on the scope of the Treaty concerning the rules that fulfilled the requirements for the exception introduced in Walrave and Donà cannot be relied on to argue that the sporting activity governed by those rules falls outside of the scope of the Treaty. There is no such thing as a general exception for sports under the Treaty.

In the paragraph 27 of Meca-Medina the Court used the new language that resulted in giving that paragraph the false reputation of severely limiting the scope of the purely sporting exception that originated in paragraphs 8 and 9 of Walrave. Having set out its position from the previous case law, it said that:

In the light of all these considerations, it is apparent that the mere fact that a rule is purely sporting in nature does not have the effect of removing from the scope of the Treaty the person engaging in the activity governed by that rule or the body which has laid it down. ${ }^{108}$

All the Court does here is re-state what is already clear 'in the light of the above considerations': if a certain rule is purely sporting, it does not mean that person engaged in the activity governed by that rule cannot rely on the Treaty in regard to any other rule that governs that activity, and it does not mean that a body that adopted a rule considered purely sporting will be removed from the scope of the Treaty in regard to other organisational rules it lays down. In either case, the fact that the Court uses the language of 'it is apparent' would imply that it does not change

\footnotetext{
${ }^{103}$ Meca-Medina, para 22.

104 Ibid., para 25 (citing Walrave, para 8).

105 Ibid., para 26.

106 Ibid., para 26 (citing Bosman, para 76, and Deliège, para 43, emphasis added).

107 Bosman, para 69.

${ }^{108}$ Meca-Medina, para 27.
} 
anything in regard to the previous case law. Weatherill thought that a possible interpretation of the decision in Meca-Medina would hold that the so-called rule of 'purely sporting interest', originating in Walrave and Koch, has now been eliminated as a basis for immunising sports rules which have an economic effect from review under EU law. ${ }^{109}$

Thereafter, the Court overruled the decision of the General Court by finding an error in the interpretation of law. It held that:

even if those rules do not constitute restrictions on freedom of movement because they concern questions of purely sporting interest and, as such, have nothing to do with economic activity, that fact means neither that the sporting activity in question necessarily falls outside the scope of Articles [101 TFEU] and [102 TFEU] nor that the rules do not satisfy the specific requirements of those articles. However, in paragraph 42 of the contested judgment, the [General Court] held that the fact that purely sporting rules may have nothing to do with economic activity, with the result that they do not fall within the scope of Articles [45 TFEU] and [56 TFEU], means, also, that they have nothing to do with the economic relationships of competition, with the result that they also do not fall within the scope of Articles [101 TFEU] and [102 TFEU]. In holding that rules could thus be excluded straightaway from the scope of those articles solely on the ground that they were regarded as purely sporting with regard to the application of Articles [45 TFEU] and [56 TFEU], without any need to determine first whether the rules fulfilled the specific requirements of Articles [101 TFEU] and [102 TFEU], as set out in paragraph 30 of the present judgment, the [General Court] made an error of law. ${ }^{110}$ Therefore, the rules found to be purely sporting for the purpose of freedom of movement provisions are not by virtue of that fact also excluded from the assessment under competition law provisions. They have to satisfy the requirements of both sets of the Treaty rules separately. A generous approach of the General Court to the scope of sporting autonomy was quashed and tighter legal requirements for compatibility of the rules of governing bodies with EU law were set by the Court. Weatherill saw the overruling of the General Court judgment not as a criticism to the convergence thesis, but as the Court pointing out the inadequacy of the General Court analysis. ${ }^{111}$ Indeed, the Court had merely reminded us that the two sets of provisions protect different freedoms of action and include different elements and that those differences deserve recognition.

The Court's position can be explained by reference to the constitutional limitations, and presumptions in Article 101 TFEU. Namely, the constitutional limitations on the action of the Union institutions operate generally, but their specific influence might be different in different substantive Treaty provisions. For example, with regard to the principle of subsidiarity in Article 5 of the Treaty on the European Union (TEU) purely internal situations fall outside the scope of internal market rules and, therefore, are not under the Union's competence. ${ }^{112}$ Nevertheless, the EU competition rules may apply even if the situation is purely internal, as

\footnotetext{
${ }^{109}$ Weatherill 2008, p 345.

${ }^{110}$ Meca-Medina, paras 31-33 (emphasis added).

111 Weatherill 2008, p 342.

112 Case 175/78 Regina v. Saunders [1979] ECR 1129; See also Cases C-225 to 227/95 Kapasakalis, Skiathis and Kougiagakas v. Greece [1998] ECR I-4329.
} 
long as there is a required effect on competition. Similarly, the notion of appreciability delimits the respective competences between Member States and the Union with regard to competition provisions, but it has no real counterpart in the internal market area. Hence, restrictions on competition which do not produce an appreciable effect on trade between Member States are not subject to EU law with respect to competition provisions, but it may be examined under the free movement articles. Therefore, paragraph 31 of Meca-Medina works in reverse too and the Court could have produced equal effect by saying:

even if those rules do not constitute restrictions on competition because they do not produce appreciable (economic) effect on trade between Member States and, as such, are not a subject of Union competence under competition provisions, that fact means neither that the (sporting or other) activity in question necessarily falls outside the scope of the free movement provisions nor that the rules do not satisfy the specific requirements of those articles.

The formalistic application, in which the effect of fundamental Union principles under one article could determine the outcome under another would deprive those other Treaty articles of their proper function. Thus, the competence to act is generally not transplantable from competition to internal market articles and vice versa. Neither specific exceptions, nor general constitutionally-based limitations can produce a generic effect of excluding a subject matter of the scope of the Treaty articles.

The language in paragraph 31 of Meca-Medina can be further explained by the difference in presumptions. With regard to cases that involve the specificity of sport, the internal market does not have the equivalent of the hard-core restrictions in Article 101(1) TFEU. In sports cases, both directly discriminatory and merely restrictive rules are treated within the same analytical framework. However, under Article 101(1), if a rule constitutes a 'per se' or hard-core restriction by object, it is not open to the parties to argue that it in fact does not amount to a restriction and the presumption of a breach of that provision is conclusive, as opposed to rebuttable. In that case, a rule that has satisfied all the requirements for the category II exception under the free movement provisions cannot benefit from the attempt at that exception under Article 101(1) to which it would otherwise be entitled but for the hard-core restrictions and conclusive presumptions of the breach. A party may rely on Article 101(3), but not on any of the judicially-developed exceptions available for ancillary restraints analysis under Article 101 (1) TFEU. Conversely, if there is no conclusive presumption under the competition provisions and the rule has already been regarded under internal market articles as 'purely sporting', this interpretation can be transposed to competition law cases with no further analysis required. The paragraph 31 in Meca-Medina should be read in this light. Once there is a rebuttable presumption under EU competition law articles and the 'required economic effect' is established under both sets of provisions, all other conditions for an exception are the same. ${ }^{113}$

${ }^{113}$ Pijetlovic 2015, pp 222-223. 


\subsection{Judgment of the Court: the test}

Finally, the Court directed its attention to the application of Article 101(1) TFEU. Relying on its previous ruling in Wouters, the Court emphasised the need for a contextual approach:

Not every agreement between undertakings or every decision of an association of undertakings which restricts the freedom of action of the parties or of one of them necessarily falls within the prohibition laid down in Article [101(1) TFEU]. For the purposes of application of that provision to a particular case, account must first of all be taken of the overall context in which the decision of the association of undertakings was taken or produces its effects and, more specifically, of its objectives. It has then to be considered whether the consequential effects restrictive of competition are inherent in the pursuit of those objectives (Wouters and Others, paragraph 97) and are proportionate to them. ${ }^{114}$

The fact that the doping rule was intended to safeguard the objective of fair play and ethics in sports did not exclude it from the scope of competition rules; the economic effects that it produced had to be considered in the light of the Wouters inherency test and the requirement of proportionality. The rule was found to restrict athletes' freedom of action, but to the extent that the general objective was to provide a level playing field and preserve integrity of sporting competition and the sanctions were necessary to ensure compliance with the doping ban, the restrictions were deemed inherent. The Court also found that athletes did not demonstrate that the controversial rule was disproportionate and upheld the previous finding of the Commission on this point.

So the athletes lost. Of particular importance is that they did not lose because the rules were of 'purely sporting' interest, but because these rules satisfied the test laid down by the Court in paragraph $42 .{ }^{115}$

According to that test, an organisational sporting rule or practice that is found to restrict the freedom of action under Article 101(1) or 102 may not breach those provisions to the extent that the rule in question pursues a legitimate objective, its restrictive effects are inherent in the pursuit of that objective and are proportionate to it. The process of assessing the compatibility of the rules under the internal market objective justification test, therefore, involves essentially the same analytical points as the test under paragraph 42 of Meca-Medina.

In Meca-Medina, just as in Wouters, the Court applied a moderate intensity proportionality test. ${ }^{116}$ This intensity would usually vary depending on the restriction in question. It does not follow from Meca-Medina that the Court has given any special consideration to sport in this regard.

\subsection{Final remarks}

The Meca-Medina judgment hit closer to the core of sporting autonomy than any other judgment prior to it. Needless to say, it was not welcomed by the sporting bodies. In particular,

\footnotetext{
${ }^{114}$ Meca-Medina, para 42.

115 Weatherill 2008, p 345.

${ }^{116}$ Lavrijssen 2010, pp 636-659.
} 
the IOC and the two largest football governing bodies (FIFA and UEFA) considered it as an attack on their authority and an unnecessary intrusion into the scope of their sporting autonomy. UEFA's Director of Legal Affairs commented on the judgment in Meca-Medina saying that it has opened up a possibility for almost any sports sanction for any offence (e.g. doping, matchfixing, gambling, bad conduct, etc.) to be described as representing a condition 'for engaging in' sporting activity and be challenged under EU competition law. ${ }^{117}$ However, the fact that sporting rules would be scrutinised under the competition provisions does not mean that they are necessarily found in breach of those provisions. Justified and proportionate rules withstand any legal challenge. But the concerns of the sporting bodies seem to disregard of this fact. MecaMedina has opened a door for new possibilities to challenge most of the organisational sport rules and could arguably lead to a substantial increase in litigation.

\section{Annex I framework for analysis of organisational rules in sport}

\subsection{General structure}

This general framework is set out in the 2007 Commission Staff Paper, Annex I entitled Sport and EU Competition Rules. In paragraph 2.1.2 of Annex I the Commission divided the approach to organisational rules in sport into four distinct steps. Step 1 includes an enquiry on the nature of the body that adopted the rule, for instance, whether the sports association that adopted the rule is to be considered an undertaking or an association of undertakings. As explained below in Annex I, these may include individual athletes, sport clubs and national and international sporting associations. Whereas this step essentially comprises an applicability test, Step 2 contains the regulatory ancillarity test and raises the question on the existence of restrictions on competition within the meaning of Article 101(1) TFEU and/or an abuse of a dominant position under Article 102 TFEU. The answer to this question depends on the outcome of the MecaMedina/Wouters test. The rule or practice adopted by an undertaking or association of undertakings which is found to satisfy the cumulative criteria of the Meca-Medina/Wouters test is considered compatible with Articles 101 and 102 TFEU. Should the rule or practice fail to meet any of the criteria, it would breach Article 101(1) and/or would constitute an abuse contrary to Article 102 TFEU. Nevertheless, another condition has to be satisfied to finally reach this conclusion: Step 3 refers to the requirement that any restriction or abuse, if found, must have an appreciable effect on trade between Member States in order to breach EU competition rules. Step 4 represents the exemption stage of analysis. It is a final, but relatively insubstantial, lifeline for a restrictive or abusive sporting rule with an appreciable effect on intra-Union trade. It examines whether a restrictive rule fulfils the conditions of Article 101(3) TFEU or the equivalent economic efficiency test under Article 102 TFEU as described above in Section 4.1. It must be acknowledged that it is highly unlikely that a rule of a sporting organisation pursuing a non-competition goal that cannot be translated into economic efficiencies or a rule that has failed the Meca-Medina/Wouters test on the point of

${ }^{117}$ Infantino 2006, pp 3-4. 
proportionality would satisfy the requisite economic conditions. ${ }^{118}$ That outlines yet another raison d'être of the Wouters test in the sporting context, for without it, the broad scope of Article 101(1) would most likely render virtually any organisational rule of sport that restricts the freedom of action and relies on the non-competition justification incompatible with the entire Article 101 TFEU.

\subsection{Organisational rules not likely to infringe Articles 101 and 102 TFEU}

In Annex I the EU Commission, as a matter of general guidance, provided a list of examples of rules likely not to infringe the competition articles. Due to a very high degree of convergence between internal market and competition law analytical structures and their respective identical outcomes with regard to the legality of rules, the list was partly generated from internal market case law. Annex I specifies that the legitimate objectives of sporting rules would normally relate to the 'organisation and proper conduct of competitive sport'. ${ }^{119}$ The following types of rules constitute examples of organisational sporting rules that, based on their legitimate objectives, are unlikely to violate competition law, provided that the restrictions contained in such rules are inherent and proportionate to the objectives pursued:

- Rules of the game (e.g., the rules fixing the length of matches or the number of players on the field) typically do not have any economic effect and would fall under paragraph 4 of Walrave; - Rules concerning selection criteria for sport competitions, such as in Deliège discussed above in Section 2.3 in internal market context, would produce identical results under competition provisions due to the virtually identical test;

- 'At home and away from home' rules such as in Mouscron decision (discussed above in Section 6);

- Rules preventing multiple ownership in club competitions such as in ENIC, discussed above in Section 6;

- Rules concerning the composition of national teams, such as in Walrave case (discussed above in Section 2.1);

- Anti-doping rules such as in Meca-Medina case (discussed above in Section 7);

- Rules concerning transfer periods, also referred to as 'transfer windows', such as in Lehtonen case (discussed above in Section 2.2) and;

- Licensing systems for sport clubs/teams in professional league competitions are also likely to satisfy the Meca-Medina/Wouters test. Such rules are intended to ensure the financial stability of clubs/teams (and, thus, the regularity of sport competitions) and the availability of proper and safe sport facilities. These rules are considered inherent in and necessary for the organisation of sport, but the proportionality will be carefully reviewed where they may interfere with business decisions of clubs/teams. The break-even requirement in UEFA's Club Licencing and Financial Fair Play Regulations is currently facing a legal challenge before the CJEU in the Striani case. ${ }^{120}$

\footnotetext{
${ }^{118}$ Commission Staff Working Paper, Annex I, para 2.1.6, says that 'such a justification is most likely to apply where a rule is not inherent in the organisation or proper conduct of sport so as to justify the application of Wouters but where the beneficial effects of a rule outweigh its restrictive effects.'

${ }^{119}$ Commission Staff Working Document, Annex I, para 2.1.5.

${ }^{120}$ Case C-299/15 Striani and Others, lodged on 19 June 2015. Read more in Ben Van Rompuy (2015) The Brussels Court Judgment on Financial Fair Play: A Futile Attempt to Pull off a Bosman,
} 
The Commission also composed a list of rules with a higher likelihood of causing problems concerning compliance with competition law; nonetheless, it added that some of them could be justified under certain conditions of Article 101(3) or Article 102 TFEU. It must be emphasised that some of the rules mentioned in this category are capable of passing the MecaMedina/Wouters assessment:

- Rules protecting sports associations from competition have been evaluated for their compatibility with EU competition law in the FIA case and in the Court's MOTOE case, discussed above in Section 5. Motor sports, especially Formula One, are more akin to business than to sport. ${ }^{121}$ The restrictive organisational rules in those cases were intended to protect private commercial interests. There are, however, some other sports governing bodies that prohibit the formation of alternative leagues by the member clubs or condition the entry to the organisational market upon fulfilment of certain criteria, but that might be justifiable on the basis of public interest objectives. Such clauses may pass Meca-Medina/Wouters and the internal market objective justification tests, but will be subject to a strict proportionality analysis. An example of such a rule is Article 49 of UEFA Statutes that can be justified on the basis of solidarity mechanisms that enable the fulfilment of the socio-cultural functions of football and work to preserve a certain financial and sporting balance between clubs and an effective and proper organisation of sport. Elsewhere I argued that certain UEFA conditions implementing Article 49 of its Statutes would have to be amended to pass the proportionality test. $^{122}$

- Rules excluding legal challenges of decisions by sports associations before national courts. The denial of access to ordinary courts, which may facilitate anti-competitive agreements or conduct was addressed in the FIA case, discussed above in Section 5 and in the FIFA case. One of the Commission's objections in FIA related to the lack of possibility to challenge FIA decisions outside the FIA structure. FIA was forced to insert a new clause clarifying that anyone subject to its decisions can challenge them before national courts as a safeguard against unjustified refusals of licenses. Similarly, throughout negotiations with FIFA on transfer rules in case of valid contracts, the Commission insisted that arbitration would be voluntary and would not prevent recourse to national courts, which led to FIFA modifying its transfer rules to this end. ${ }^{123}$ Sporting associations usually do have arbitration clauses in their commitment agreements with players. Some of them contain clauses that facilitate anti-competitive practices, such as the ones imposed by tennis governing bodies. ${ }^{124}$

\footnotetext{
http://www.asser.nl/SportsLaw/Blog/post/the-brussels-court-judgment-on-financial-fair-play-a-futile-attempt-topull-off-a-bosman-by-ben-van-rompuy\#_ftnref5. Accessed 10 July 2015.

${ }^{121}$ Cygan 2007, p 76.

122 Pijetlovic 2015, pp 290-301.

${ }^{123}$ Commission, Staff Working Document, para 2.2.2.2; See also Report from the Commission - XXXIst Report on Competition Policy 2001, SEC/2002/0462 final, para 220.

${ }^{124}$ Pijetlovic 2013, pp 161-186.
} 
- Rules concerning nationality clauses for sport clubs/teams, such as quota requirements in Bosman. Today it is clear that these directly discriminatory rules will infringe free movement provisions and, therefore, any economic justifications they could produce under the economic efficiency defence will not have an effect on their illegality under internal market provisions. Whereas the rules challenged under both internal market and competition law must pass both tests to be considered legal, it is sufficient that they violate only one set of provisions to be considered void and unenforceable. On the other hand, indirectly discriminatory rules, such as UEFA's home-grown players rule, might be able to satisfy the internal market objective justification criteria and, therefore, survive the Meca-Medina/Wouters test. ${ }^{125}$

- Rules regulating the transfer of athletes between clubs (except transfer windows), such as transfer fees in Bosman discussed above in Section 2.2, also belong to the more problematic category of organisational rules. However, some of these rules are capable of satisfying $\mathrm{Meca-}$ Medina/Wouters test as we saw in Bernard, a case that concerned compensation fees for young players. Bosman did not address the legality of transfer fees for players who are still under contract. In 1998 the Commission issued a statement of objections concerning FIFA's Regulations for the Status and Transfer of Players, but closed the investigation in 2002 following FIFA's commitments to modify its transfer rules for in-contract players. ${ }^{126}$ The main commitments were inclusions of certain measures to support the training of players (e.g. training compensation for young players and a solidarity mechanism), establishing a transfer period per season, specification of contractual arrangements between players and clubs (e.g. regulating duration of contracts, and specifying when breaches of contracts are possible, including sanctions), and ensuring that arbitration is voluntary and does not prevent recourse to national courts in case of disputes.

- Rules regulating professions ancillary to sport were assessed under EU competition law in the Piau case in the context of the activity of players' agents. The General Court considered it an economic activity involving the provision of services which does not fall within the scope of the specific nature of sport. ${ }^{127}$ In order to acquire a licence, players' agents were required to have impeccable reputation, pass a written examination and take out professional liability insurance policy or deposit a bank guarantee. This constituted a barrier to access to that economic activity. However, because (1) the contested FIFA rules sought to protect players and their short careers for incompetent representation in transfer negotiations by raising professional and ethical standards for the occupation, (2) the compulsory license system did not eliminate the effective competition and it is based on qualitative rather than quantitative selection criteria appropriate for the attainment of the first objective, and (3) there existed no collective organisation of players' agent and no generalised national rules, the restrictions on competition brought about by the compulsory licence system could enjoy an exemption

\footnotetext{
${ }^{125}$ Study on the Assessment of the UEFA's 'Home Grown Players Rule', negotiated procedure EAC 07/2012 (30 April 2013).

${ }^{126}$ European Commission, XXXIst Report on competition policy 2001, para 220; European Commission, Commission closes investigations into FIFA regulations on international football transfers, IP/02/824 (Brussels 5 June 2002).

${ }^{127}$ Ibid., para 73.
} 
decision under Article 101(3) TFEU. ${ }^{128}$ It followed from these considerations that an abuse of a dominant position under Article 102 TFEU could also not be established. ${ }^{129}$

In 2009 the Commission funded an independent study on sport agents. The main concerns identified were of an ethical nature, including financial crime and exploitation of young players. $^{130}$

\subsection{Comment}

Both of the lists in Annex I are non-exhaustive and were composed exclusively on the basis of existing case-law. Even though there is a lot of fluidity, it can be concluded that the overall difference between the lists is whether the organisational rule protects public or private interests, and whether the specific nature of sport is involved. We saw in Piau that even where the rules protected public interests, but were not connected to the notion of the specificity of sport, the General Court did not refer to the possibility of regulatory ancillarity, but simply concluded that restrictions existed. Protecting private interests, the lack of connection to the specific nature of sport or direct discrimination (other than the purely sporting rules within the meaning of paragraphs 14 and 15 of Donà), will eliminate the possibility of passing MecaMedina/Wouters test. As a matter of law, such rules may nevertheless benefit from commercial ancillarity or the Article 101(3) exemption and the equivalent defences under Article 102 TFEU. It would not influence the outcome if the claimant also brought action under internal market provisions.

Some important outstanding issues that have not been subject to either a Commission or a Court's decision are uncompensated player release rules, salary caps and the home-grown players rule. The Commission pays due caution to the fact that regardless of the tentative classification of items on the two lists, an individual analysis of every challenged organisational sporting rule on a case-by-case basis is indispensable. In its Communication on Sport the Commission further emphasises that through dialogue with sports stakeholders it will continue its efforts to explain on a theme-per-theme basis the relation between EU law and sporting rules. $^{131}$ The sports governing bodies nonetheless need to be careful not to take the Commission's opinion as a final say on the legality of their rules. The fact that a rule is drafted in collaboration with the Commission does not shield it from judicial scrutiny or provide any guarantees as to its compatibility with EU law. The Commission does not have the power to authorise rules and practices that are contrary to the Treaty.

\footnotetext{
${ }^{128}$ Ibid., paras 102-104.

${ }^{129}$ Ibid., para 119.

${ }^{130}$ Study on Sports Agents in the European Union (2009), commissioned by the European Commission, DG for Education and Culture. http://ec.europa.eu/sport/library/studies/study-sports-agents-in-eu.pdf. Accessed 10 July 2015.

${ }^{131}$ Communication from the Commission to the European Parliament, the Council, the European Economic and Social Committee, and the Committee of the Regions, Developing the European Dimension in Sport, COM (2011) 12 final, para 4.2 .
} 


\section{References}

Baquero Cruz J (2002) Between Competition and Free Movement: The Economic Constitutional Law of the European Community. Hart Publishing, Oxford.

Craig P, De Búrca G (2011) EU Law. 5th edn Oxford University Press, Oxford

Cygan A (2007) Competition and Free Movement Issues in the Regulation of Formula One Races. In: Bogusz B et al. (ed) The Regulation of Sport in the European Union, Edward Elgar, Cheltenham, pp 74-94

Faull J, Nikpay A (2007) The EC Law of Competition. 2nd edn Oxford University Press, Oxford.

Foster K (2006) Lex sportiva and lex ludica: The CAS's jurisprudence. In: Blackshaw I et al. (ed) The CAS 1984-2004, T.M.C. Asser Press, The Hague, pp 420-440

Infantino G (2006) Meca-Medina: A Step Backwards for the European Sports Model and the Specificity of Sport? Sports Law: Administration and Practice 13:3-4

Lavrijssen S (2010) What Role for National Competition Authorities in Protecting NonCompetition Interests After Lisbon? European Law Review 35:636-659

Miettinen S (2009) Policing the Boundaries between Regulation and Commercial Exploitation: Lessons from the MOTOE Case. In: Gardiner S et al. (ed) EU, Sport, Law and Policy, T.M.C. Asser Press, The Hague, pp 137-149

Monti G (2002) Article 81 and Public Policy. Common Market Law Review 39:1057-1099

Mortelmans K (2001) Towards Convergence in the Application of the Rules on Free Movement and on Competition? Common Market Law Review 38:613-649.

Parrish R, Miettinen S (2008) Sporting Exception in European Union Law. T.M.C. Asser Press, The Hague

Pijetlovic K (2013) Fundamental Rights of Athletes in the EU post-Lisbon. In: Kerikme T (ed) Protecting Human Rights in the EU: Controversies and Challenges of the Charter of Fundamental Rights, Springer, Heidelberg, pp 161-186

Pijetlovic K (2015) EU Sports Law and Breakaway Leagues in Football. Springer/T.M.C. Asser, The Hague

Semmelmann C (2008) The Future Role of the Non-Competition Goals in the Interpretation of Article 81 EC. Global Antitrust Review 1:15-47 
Whish R (2009) Competition Law. $6^{\text {th }}$ edn Oxford University Press, Oxford

Weatherill S (2008) Anti-Doping Revisited - the Demise of the Rule of 'Purely Sporting Interest? In: Weatherill S, European Union Sports Law: Collected Papers, T.M.C. Asser Press, The Hague, pp 335-352 